\title{
IMPROVING WRITING SKILL OF RECOUNT TEXT THROUGH GIVING CHAIN AND QUESTIONS TECHNIQUES IN SMAN 3 TEBING TINGGI
}

\author{
Puji Dwi Sulastri \\ English Teacher TebingTinggi, South Sumatera \\ E-mail:puji@gmail.com \\ Received on Feb, $18^{\text {th }}$, Revised on April $8^{\text {th }}$, Published on July,31 2019
}

\begin{abstract}
This classroom action research aims to improve students' skills in writing recounts using chain drawing techniques and several questions.The subjects of this study were students X IIS.1 SMA 3 TEBING TINGGI 2017/2018 lessons, amounting to 22 people consisting of 11 men and 11 women.In collecting data, recount writing and observation or observation tests are conducted.All data are collected and analyzed. In analyzing the results of the tests using a system scale the rating criteria are referent values. The results that the researchers obtained from this study were qualitative data and quantitative data.Qualitative data shows that students are very active and fluent in writing recounts, this can be seen by the increase in student activity in doing their own writing recount activities in the first cycle and second cycle, and students smoothly answer questions based on the images set out in recount essays. Whereas from quantitative data, it can be seen that there is an increase in the value of students from the level or level of information written on their recount.The number of students who get A in the first cycle is 1 meeting (1 person), 2nd meeting ( 2 people), and 3rd meeting (4 people). On the second cycle of the 1st meeting ( 9 people), 2nd meeting (17 people) and 3rd meeting (22 people). Students who get B score in cycle 1 , meeting 1 (4 people), meeting 2 ( 4 people) and meeting 3 (12 people). On cycle 2 , meeting 1st (6 people), 2nd meeting (5 people) and no B value at 3rd meeting. This means giving serial images and several questions, so that the writing skills of students X IIS.1 of SMA Negeri 3 Tebing Tinggi can be improved.
\end{abstract}

Keywords:Writing Skills, Recount Text, Chain Images

\begin{abstract}
ABSTRAK
Penelitian tindakan kelas ini bertujuan untuk meningkatkan keterampilan siswa dalam menulis recount dengan menggunakan teknik menggambar rantai dan beberapa pertanyaan. Subjek penelitian ini adalah siswa X IIS.1 pelajaran SMA 3 TINGGI TINGGI 2017/2018, berjumlah 22 orang yang terdiri dari 11 pria dan 11 wanita. Dalam mengumpulkan data, penulisan ulang dan observasi atau tes observasi dilakukan. Semua data dikumpulkan dan dianalisis. Dalam menganalisis hasil tes menggunakan skala sistem kriteria penilaian adalah nilai referensi. Hasil yang peneliti peroleh dari penelitian ini adalah data kualitatif dan data kuantitatif. Data kualitatif menunjukkan bahwa siswa sangat aktif dan fasih dalam menulis recounts, hal ini dapat dilihat dengan peningkatan aktivitas siswa dalam melakukan kegiatan recount tulisan sendiri di siklus dan siklus kedua, dan siswa dengan lancar menjawab pertanyaan berdasarkan gambar yang ditetapkan dalam esai recount. Dari data kuantitatif, dapat dilihat bahwa ada peningkatan nilai siswa dari level atau level informasi yang ditulis pada recount mereka. Jumlah siswa yang mendapat nilai A pada siklus pertama adalah 1 pertemuan (1 orang), pertemuan 2 (2 orang), dan pertemuan ketiga (4 orang). Pada siklus kedua pertemuan pertama (9 orang), pertemuan kedua (17 orang) dan pertemuan ketiga (22 orang). Siswa yang mendapat skor B pada siklus 1 , bertemu 1 (4 orang), bertemu 2 (4 orang) dan bertemu 3 (12 orang). Pada siklus 2, pertemuan 1 (6 orang), pertemuan 2 (5 orang) dan tidak ada nilai B pada rapat ketiga. Ini berarti memberikan gambar seri dan beberapa pertanyaan, sehingga keterampilan menulis siswa X IIS.I SMA Negeri 3 Tebing Tinggi dapat ditingkatkan.
\end{abstract}

Kata kunci: Keterampilan Menulis, Menulis Ulang Teks, Gambar Berantai

P-ISSN 2614-7343 | E-ISSN 2621-5128

Vol. 2 No.2 July 2019

131

Edu-Ling Journal, https://journals.unihaz.ac.id/index.php/edu-ling 


\section{INTRODUCTION}

Teaching English in high school is expected so that students can communicate both verbally and in writing which is realized in four language skills, namely: listening, speaking and writing skills (Diknas, 2006: 307).Writing skills have great uses and have an important role in life (Langacker, 1999: 59).

One of the writing skills that needs to be developed is recount writing skills.In the 2013 curriculum in English class X semester II writing skills are said that students can express meanings in written text simple essays in the form of recount in the context of daily life, and also in basic competencies it is said that students can express meaning and steps rhetorically accurate, smooth and acceptable by using a variety of written languages in the context of daily life in recounted texts.

From the results of the author's observation, it was found that students' ability to write recount skills was still very low, this can be seen from the results of their recount writing that did not meet the criteria for recount writing, so the results were also low, with scores below 65, whereas the minimum completeness criteria (KKM) specified in the English class $\mathrm{X}$ class are set at 65 .
The criteria for recount writing a student must pay attention to the language function or grammar, vocabulary, and generic structure or rcount writing arrangement.The composition of the recount writing consists of three parts or three paragraphs, namely Orientation, Series of Events and Reorientation.In the paragraph orientation contains about the perpetrator, what happened, where the event occurred and when it happened.In the paragraph section the Series of Events contains a series of events written in chronological order. In the Re-Orientation section, it contains conclusions from the path of events.Students' inability to express their ideas in recount writing is because they have never been trained and they do not know what to write and how to write it.To overcome this problem, as an effort to improve students' recount writing skills, researchers used a chain drawing technique and several questions.The reason the researchers chose the technique is because this technique facilitates and expedites students in writing recounts because if all the questions are answered completely based on the sequence of the serial images, it will form a good and correct recount essay.

The researcher estimates that by applying the chain drawing technique and several questions can improve recount 
writing skills for all students of class X IIS.1 in TebingTinggi State High School 3 South Sumatra.Based on the problems described above, researchers chose a research title Writing Skills ImprovementRecountX IIS.1 SMA Negeri 3 TebingTinggiThrough Giving Mechanical Image Chain and Questions.And the purpose of this study was to find out whether through the provision of chain images and several questions, the recount writing skills of class X IIS students could increase

\section{METHODOLOGY}

This research was an action research carried out in class X IIS. 1 This study was focused on investigating whether through the technique of serial drawing and several questions can improve the writing skills of class X IIS.1SMA Negeri 3 TebingTinggi.

The research location is at SMA 3 TebingTingg with a sample of class X IIS students. English Language Lessons for the school year 2017/2018. The time of the study will be held from January to April 2018 in class IIS students. lesson 2017 / 2018SMA Negeri 3 TebingTinggi.This research will be held every Wednesday in accordance with the hours of learning English in class X IIS.1 which is the object of research.As the subject of this study were students of class X IIS.1SMA Negeri 3

TebingTinggi. Students of this class were taken as the subject of research because in this class the learning activities of students in writing Recount were only a small part of reaching KKM.In addition, most students are passive in learning English, especially in writing recount activities.This factor is thought to be a factor in the low value of writing student recounts.

\section{Researcher's Observation Instrument During Writing Recount Activities for Students}

This sheet is used to see and observe student activities during the learning process whether they are active or not in writing recount activities. This sheet contains several aspects observed, namely: a) Positive Activity, 1) Doing Your Own Job. 2) Don't See Words in Dictionary, b) Negative Activity 1) Asking friends, 2) Modeling the Answer Sentences from Friends, c) See Words in Dictionary Interfere with friends Frequently Asking for Permission to Exit.

\section{Instrument Assessment of Student Writing Results}

This instrument contains about, Grammar, Vocabulary, Spelling, Table of contents, Punctuation, Percentage of Writing Recount Value. 


\section{Kolaberator Observation Instrument}

This instrument contains several aspects observed by collaborators as long as students carry out writing activities and as long as the researcher explains the lesson on student recount writing activities.

The data analysis technique used is using the Refresh Value Rating Criteria Scale.On this sheet contains the level or level of students' writing skills which consists of ranking grades A, B, C, D, E.

Value A states that the percentage of the correct answer is $93 \%$ to $100 \%$. This value is at the Very Skilled Level. Value B states that the percentage of the correct answer is $85 \%$ to $92 \%$. This value is at Skilled Level. Value $\mathrm{C}$ states that the percentage of the correct answer is $75 \%$ to $84 \%$.This value is at a sufficiently skilled level. Value D states that the percentage of the correct answer is $60 \%$ to $74 \%$. This value is at the unskilled level.

The Evalue states that the percentage of the correct answer is below 60\%.This value is at the Very Skilled or Failed Level.

\section{Criteria System Scale Reference Value Rating}

\begin{tabular}{|c|c|c|c|}
\hline No & $\begin{array}{c}\text { Percentage } \\
\text { of Answers } \\
\text { Benar }\end{array}$ & Indigoi & Level (Level of Achievement) \\
\hline 1 & $93-100 \%$ & A & Outstanding (Very skilled) \\
\hline 2 & $85-92 \%$ & B & $\begin{array}{l}\text { ABOVE AVERAGE } \\
\text { ACHIEVEMENT } \\
\text { (Skilled) }\end{array}$ \\
\hline 3 & $75-84 \%$ & $\mathrm{C}$ & AVERAGE ACHIEVEMENT (Quite skilled) \\
\hline 4 & $60-74 \%$ & $\mathrm{D}$ & BELOW AVERAGE (Not skilled) \\
\hline 5 & $>60 \%$ & $\mathrm{E}$ & $\begin{array}{l}\text { INSUFFICIENT } \\
\text { ACHIEVEMENT } \\
\text { (VERY Skilled/Failed) }\end{array}$ \\
\hline
\end{tabular}

The teaching material from this study is the activity of writing recount as stated in the appendix of this report. This research was conducted in 2 cycles with each cycle held three times.Every time the meeting uses a chain image and a few questions. As for those involved in the research of class action, the researchers themselves as English teachers at SMA 3Tebing Tinggi were assisted by 1 English teacher who taught class XI AND XII at SMA 3 TebingTinggi.

\section{RESULT AND DISCUSSION}

\section{Cycle I}

This research was conducted by the researchers themselves and assisted by two 
English teachers as observers. The research in the first cycle is planned to be held for 3 meetings with a time of 1 meeting for 45 minutes. The time for conducting research in this first cycle is First Meeting: Wednesday, 10 January 2019. Second Meeting: Wednesday, 17 Janurari 2019. Third Meeting: Wednesday, September 24, 2019.

As soon as the implementation of research activities follows systematics as the following: Action Planning, Implementation of Action, Observation and Reflection.

\section{Action Planning}

In this first cycle research carried out learning with action plan as follows. Activity A Week Before; a) make a Learning Implementation Plan (RPP) for three meetings, b) Make and multiply student work sheets containing chain images and several questions, c) Create and prepare several assessment sheets for student writing activities or some data collection instruments, d) Create and prepare a rating scale in the form of a system of rating criteria referential value.

Activities at the time of learning, share student worksheets containing chain images and several questions, carry out the learning implementation plan (RPP), conducting observations on writing student recount activities during learning, strengthening at the end of learning and closing learning by giving follow-up.

\section{Implementation of Action}

The implementation of the action in this study was designed in RPP (Learning Implementation Plan) and implemented in the process of learning students in the classroom.Every face advance is given to students the student worksheet containing chain pictures and a few questions. As for the sequence of actions is as follows:

Initial Activity. The teacher opens the lesson by greeting members and greeting and checking student attendance.

Core Activities

1. The teacher holds questions and answers to classmate about the experiences they experienced for some time ago.

2. The teacher distributes several sheets of paper to students containing chain images and several questions.

3. The teacher asks students to observe the chain images and the questions.

4. The teacher holds a question and answer discussion with classmates about pictures and questions so that all the answers can be in the form of an essay.

5. The teacher asks students to write their answers in the form of a paragraph recount not in the form of sentences sorted from top to bottom. Final Activity, 
The teacher concludes the material that has been studied with students. The teacher tells about the learning material the following week.

\section{Observation}

During the learning process takes place, student activities in working on writing a recount with a chain image and several questions observed by researchers and colleagues involved in this study for 3 meetings in the learning process for one cycle using data collection tools, observation sheets or observation sheets and assessment sheets about recount writing aspects namely about grammar, vocabulary, spelling, contents and punctuation which will then be analyzed at the end of the first cycle as consideration in determining learning activities in the next cycle.

\section{Reflection}

At each meeting for three meetings, the results of research observations and peers were analyzed to determine the level of achievement of students' recount writing skills through chain drawings and several questions. The results of reflection of data obtained at the end of cycle I are presented in the form of data, tables and graphs that are useful for determining plans in the next research cycle.

\section{Cycle 2}

The research in the second cycle is almost the same as the first cycle, the second cycle of research was carried out on the method of writing recount using a chain image and several questions. The chain images in the second cycle are different from the images in cycle 1 . As for the time of the research in the second cycle, they are:

\section{Action Planning}

Learning planning in the second cycle is almost the same as the first cycle, the difference in the second cycle is that there are several changes to the action plan as additional actions during the implementation of learning.The systematics of action plans are as follows; a) explain to students the language focus contained in the question of grammar in the form of simple past tense, b) carry out the learning implementation plan according to the learning material, c) share students' worksheets or student worksheets according to the subject matter.

\section{Implemention of Action}

The activity plan that has been designed in the learning implementation plan as a learning scenario is carried out in the learning process of students in the classroom. Every face to face uses Students' 
worksheets which have chain images and several questions below with the same sequence of actions as the first cycle, namely, teacher Action The previous week as a difference in action from cycle to 1 which is an additional action in the second cycle, namely, a) explain to students about the use of simple past tense contained in the question, b) explain to students how to answer questions so that the answer to the question can be a recount essay, c) Initial activity, d) the teacher opens the lesson by greeting members and greeting and checking student attendance.

Core activities includes the teacher distributes several sheets of paper to students containing chain images and several questions, a) the teacher explains to students about the use of simple past tense and some questions from the chain images that use simple past tense, b) the teacher asks students to observe the chain images and the questions, c) the teacher holds a discussion Questions and answers with classmates about the picture and the question so that all the answers can be in the form of an essay. d) the teacher asks students to write their answers in the form of a paragraph recount not in the form of sentences sorted from top to bottom. End activities includes the teacher concludes the material that has been studied with students and the teacher tells about the learning material the following week.

\section{Observation}

During the learning process, students' activities in working on recount writing through pictures and several questions were observed continuously by researchers and colleagues involved in this study for 3 meetings in the learning process for one cycle by using observation data collection tools or observation sheets and sheets assessment of aspects of recount writing regarding grammar,vocabulary, spelling, contents and punctuation which will then be analyzed at the end of the second cycle as consideration in determining learning activities in the next cycle.

\section{Reflection}

At each meeting for 3 meetings, the results of observations of researchers and colleagues were analyzed to determine the level of achievement of students' recount writing skills through chain drawings and several questions. The results of reflection of data obtained at the end of the second cycle are presented in the form of data, tables and graphs that are useful for determining the plan in the next research cycle. 


\section{RESULTS AND DISCUSSION}

\section{First Cycle Research Results}

Based on the results of observations of researchers so far, students lack skills in writing recounts. The inability of students to write recount is because most students do not know what to write and do not know how to write it. To help with this difficulty, the researcher guides students in writing recounts using the technique of giving chain images and several questions.

Learning objectives after following the learning process students are expected to be able to, 1) correctly answer all questions given based on the sequence of images, 2) write smoothly and correctly in the form of a recount essay based on a chain image and a number of questions given, 3) In this first cycle the learning scenarios created are students are asked to observe the chain images given along with the questions and the teacher holds a question and answer discussion with classmates about the pictures and questions one by one, 4) the teacher trains students to write answers one by one from several questions given based on the sequence of images in the form of a recount essay.

In order for all the above activities to run well, the teacher prepares learning media and research instruments. Learning media used are chain images, while referense value ranking criteria, observers 'observation sheet on student activities during the action, student recount writing skills assessment sheet and observation sheet of collaborator observation on students' recount writing activities through techniques of chain drawing and questions .

\section{Implementation}

The action in the first cycle was carried out 3 times and went according to the scenario that had been made. At the first meeting, the learning activities began with the researcher by giving greetings and greetings and checking the attendance of students. After class conditions allow, the researcher continues the learning activities by mentioning the objectives and learning material, then the researcher holds a question and answer session to classmates about the experiences they experienced some time ago, after which the researchers distributed several sheets of paper to students containing chain images and several the question. Next the researcher asks students to observe the chain images and the questions, then the teacher holds a question and answer discussion with classmates about the pictures and questions. In order for the sentences of answers to be in the form of a recount essay, the teacher asks students to 
write the answers in the form of a recount essay not in the form of sentences sorted from top to bottom. Finally, the teacher concludes that the material is still being studied with students and tells students about the learning material the following week in the second and third meetings, learning activities are not too different from the first meeting, only in the second and third meetings, the core activities are given other chain images and questions. others too.

\section{Observation}

In general, learning activities are in accordance with the learning plan. All changes that have occurred have been recorded by the researcher. The results found in the first cycle of the results of observations / observations of researchers and two collaborators on student activities during the recount writing activity are that there are 5 people doing their own work (1st meeting), 7 people (2nd meeting) and 10 people (meeting the 3rd). Students who don't see the word in the dictionary have 5 people (1st meeting), 3 people (2nd meeting) and 5 people (3rd meeting). There were 21 people each at meetings 1,2 and 3 who still asked friends when writing recounts.

Examples of answers from friends are 22 people (meeting 1), 19 people (meeting 2) and 12 people (meeting 3). Students also still see words in the dictionary as many as 17 people (meeting 1), 19 people (meetings 2 and 3). In addition there are also students who like to disturb their friends when writing recount as many as 2 people (meeting 1) and 1 person at the second and third meetings. There are also students who often ask for permission to leave as many as 8 people (meeting 1), 12 people (meeting 2) and 4 people (meeting 3 ).

From the data obtained in the first, second and third meetings in the first cycle, it can be concluded that there are still a few students who do their own work writing recounts, they still ask a lot of friends and follow the answers from friends and they often ask permission to leave, then the second cycle needs to be held to follow up.

For the aspect of assessment, in the first cycle, students still make a lot of wrong answers in the form of a recount essay, there are 7 students at the 1st meeting, 13 people at the 2 nd meeting and 15 people at the 3 rd meeting. Most students still number the sentences of their answers and sorted down, there are 15 people at the 1st meeting, 9 people at the 2 nd meeting, and 7 people at the 3rd meeting. The use of grammar in the recount essay of students is a bit correct which is only 2 people each -each meeting 1 and 2 and there are 7 people at the 3rd 
meeting. The use of vocabulary is also only slightly correct, there are 7 people at the 1 st and 2nd meetings, but at the 3rd meeting many of them actually write it, there are 21 people at 1 st and 22nd meeting at the 2nd and 3rd meeting. Likewise with the use of punctuation marks, all of the many students who correctly use it in their recount writing are at the meeting to 1,2 and 3 .

From the data obtained in the first, second and third meetings in the first cycle, it can be concluded that the second cycle is needed because there are still many mistakes in arranging the sentence sentences in the form of a recount essay based on the sequence of images. Students also still have a lot of mistakes in using grammar, especially the use of simple past tense in writing recounts, as well as the usage listed in the tables and graphs below. From student activity data in the classroom during recount writing through observations or observations of researchers and collaborators and from the correct recount written data from students in the first cycle.

\section{Reflection}

Based on the data obtained from the observations or observations of researchers and collaborators on the activities of students in the class during writing recount, and from the value of students' recount writing skills in the first cycle, the researchers conducted reflections needed to improve actions in the second cycle, namely: 1) the researcher explains to students first that the sentences of answers to questions or contents are arranged in the form of a recount essay based on the sequence of images rather than in the form of answer sentences which are numbered and sorted down, 2) the researcher explains the use of past tense sentences contained in the question sheet. 3) the researcher explained the use of vocabulary and punctuation to students.

\section{Second Cycle Research Results}

The learning topic in this second cycle is still the same as the learning topic in the first cycle, which is writing recount through the technique of chain drawing and questions. Learning objectives after following the learning process in the second cycle, students are expected to be able to: answer correctly and smoothly all questions given based on the sequence of images and write correctly and smoothly in the form of a recount essay based on a chain image and several questions given using past tense, vocabulary, spelling, and correct punctuation. 
The learning scenario in the second cycle is as follows, a) the researcher explained in advance the use of past tense sentences contained in the question sheet, b) the researcher explained the use of vocabulary, spelling, and punctuation to student and c) the researcher explains and directs students that the sentences of answers to questions or contents are arranged in the form of a recount essay based on

Learning media used are recount chain images along with question sentences. The instruments used are observation sheets or observations from researchers about writing student recount activities, recount writing skills assessment sheets, and system scale sheets referential value rating criteria,

\section{Implementation}

The action in the second cycle begins with the researcher by entering the classroom, followed by greetings and greetings and checking the attendance of students. After class conditions allow, continue the learning activities by mentioning learning objectives and material, after which the researcher gives and distributes several pieces of paper to students containing chain images and subsequent questions, the researcher explains in advance the use of past tense sentences contained in the sheet questions, then the teacher asks students to observe the chain images and questions, then the researcher holds a question and answer discussion with classmates about the picture and questions so that all the answers can be in the form of an essay. The researcher also explained the use of vocabulary, and punctuation marks to students. Then, the researcher directed and asked students to write their answers, in the form of a good and correct recount essay using past tense, vocabulary, spelling, and correct punctuation. Finally, the researcher concludes the material that has been studied with students, then tells about the learning material for the following week.

At the end of the second cycle, student work results are assessed and corrected both at the first, second and third meetings.

\section{Observation}

The action in the second cycle took place according to the plan that had been made. During the action in the second cycle, all changes were recorded by the researcher and two collaborators.

The results found from the second cycle at the first meeting of the results of observations or observations of student activities during their recount writing 
activities are 15 students who do their own work recount writing activities, 19 people still see the word in the dictionary, 7 people follow the answer sentence from friends, 3 people often ask permission.

For the second meeting, 16 students work on their own work and 6 people still ask questions with friends, 21 people see words in the dictionary and 1 person does not. For the third meeting, there are all students, namely 22 people doing their own work and they all do not see the word in the dictionary.

As for the results of the assessment of students' writing skills from the second cycle at the first meeting, it was found that there were 2 people still using the past tense grammar, 5 students were wrong in using vocabulary, and all students did not make spelling and punctuation mistakes, 19 students answered questions or complete contents based on the image form a good and correct recount essay.

At the second meeting in the second cycle, it was found that only 2 people made mistakes in past tense grammar, for vocabulary, and punctuation did not occur from students. At the third meeting of the second cycle, all students answered questions / content completely based on the image forming a good and correct recount essay using the correct grammar of tense, vocabulary and correct spelling . The following table shows the results of the assessment of students' writing skills in the second cycle.

\section{Reflection}

From tables and graphs the level of achievement of recount writing in class $\mathrm{Xd}$ students in the first cycle and second cycle, it can be concluded that there is an increase in the level or level of achievement of writing student recount from each meeting in cycles I and 2, so it can be said that through the chain drawing technique and some questions, the recount writing skills of students X IIS.1 SMA 3 TebingTinggang increased. Therefore this research does not need to be continued to the next cycle.

\section{CONCLUSION}

Less skilled students in writing recounts because they were never trained, so they did not know what to write and how to write it. To improve these skills, one alternative is to use a chain drawing technique and several questions. Through this technique, students are easier and smoother in writing recounts. Based on the results of the research from the first cycle to the second cycle, it was found that there was 
an increase in the results obtained by students in recount writing skills. For English language teacher colleagues who want to teach recount writing skills to class $\mathrm{X}$ students can use the technique of chain drawing and several questions. The chain images can be found in illustrated story books, magazines, the internet, and the question can be made by the teacher

\section{REFERENCE}

National Education Standards Agency, 2006.Competency Standards and Basic Competencies for Subjects in High School English Curriculum 2006 . Jakarta: Ministry of National Education. Directorate General of Primary and Secondary Education.

Langacker, Ronald W. 1973. Language and Its Stucture: Some Fundamental Linguistic Concepts. San Diego: Harcourt Brace Javanovich, Inch.

Madya, Suwarsih, 994. Action Research Guide.Yogyakarta: IKIP Yogyakarta Research Institute.

Tarigan, Henry Guntur. 1991. Language Teaching Methodology .Bandung Angkasa.

Tinambunan, Wilmar. 1998 .Evaluation of Students Achievement.Jakarta:
Ministry of Education and Culture.

Directorate General of Higher Education. Educational Power Development Project. 